\title{
Adipose tissue developmental growth constraints uncouple fat distribution from glucose metabolism in two mouse models of obesity
}

\author{
Zachary L. Sebo ${ }^{1}$, Christopher Church ${ }^{2}$, Ryan Berry ${ }^{1}$ and Matthew S. Rodeheffer ${ }^{1-5}$ \\ Yale University, Department of Molecular, Cellular and Developmental Biology ${ }^{1}$, Department of \\ Comparative Medicine ${ }^{2}$, Department of Physiology ${ }^{3}$, Yale Stem Cell Center ${ }^{4}$, and Yale Program in \\ Integrative Cell Signaling and Neurobiology of Metabolism ${ }^{5}$
}

Correspondence should be addressed to:

Matthew Rodeheffer

matthew.rodeheffer@yale.edu

of Comparative Medicine

Yale University School of Medicine

375 Congress Ave

New Haven, CT 06520

Tel \#203-737-3370

Fax \#203-785-7499 


\section{Abstract} leverage two mouse models with differing quantities of visceral and subcutaneous fat to assess the role

4 of fat distribution in glucose homeostasis. Interestingly, we found genetic ablation of inguinal 5 subcutaneous fat does not exacerbate obesity-associated impairments in glucose metabolism. Consistent with this observation, mutant mice that preferentially accrue subcutaneous fat display a similar metabolic profile to controls with equal fat mass. Importantly, the increased subcutaneous adiposity in these mice occurs downstream of androgen receptor deficiency and is not driven by elevated adiponectin activity. Rather, it is caused by diminished adipocyte precursor seeding in nascent visceral fat and proportionally greater growth of subcutaneous fat. Thus, the pattern of obesogenic fat mass expansion can be determined early in development without impacting glucose metabolism. This suggests that different mechanisms underlying biased fat accumulation exert different effects on glucometabolic health.

13

\section{Introduction}

The site of adipose tissue expansion in obesity is a major determinant of cardiometabolic disease risk, with high visceral adiposity associated with incident diabetes, atherosclerosis and hyperlipidemia (Carr and Brunzell, 2004, Hartz et al., 1983, Yamashita et al., 1996). Excessive visceral fat accumulation is thought to cause an elevated release of free fatty acids (FFAs) into the circulation, leading to ectopic lipid deposition and insulin resistance in peripheral organs (Björntorp, 1990, Shulman, 2014). On the other hand, high subcutaneous adiposity, specifically around the hips and thighs, is associated with a reduced incidence of metabolic disease (Hamdy et al., 2006, Karpe and Pinnick, 2015, Manolopoulos et al., 2010). The beneficial effects of increased subcutaneous fat are thought to be associated with its capacity to function as a metabolic sink for excess lipid (Hardy et al., 2012, Tchkonia et al., 2013), which would otherwise accumulate in visceral fat and ectopically to drive insulin resistance (Shulman, 2014). This is supported by the observation that thiazolidinediones (TZDs), a family of diabetes drugs that activate 
PPARy, promote subcutaneous adiposity (Miyazaki et al., 2002, Mori et al., 1999, Carey et al., 2002, Yki-

Järvinen, 2004). The effects of TZDs are mediated partly through the upregulation of adiponectin (Joseph

et al., 2002, Kubota et al., 2006). High circulating adiponectin is associated with a greater proportion of

in these mice. Consistent with this observation, we show that the preferential accumulation of subcutaneous fat in diet-induced obesity. Thus, fat distribution in obesity can be determined early in development without overt effects on metabolism. These data imply that the specific mechanism by which biased fat accumulation occurs strongly influences the role of fat distribution in metabolic health.

\section{Results}

Inguinal subcutaneous fat is not necessary for normal glucose metabolism in obesity 
ablation of inguinal subcutaneous fat in mice would eliminate the protective effects of this depot in obesity, further impairing glucose metabolism. To prevent inguinal fat development we engineered a mouse strain (Prx1-Cre:PPARy ${ }^{\mathrm{fl} / \mathrm{fl}}$ ) that has PPARy conditionally knocked out in the hindlimbs (Fig. 1A, at 6 weeks of age followed by assessments of body composition, fat distribution and glucose metabolism. subcutaneous obesity from extended HFD feeding (Abreu-Vieira et al., 2015). Consistently, cre- male animals develop subcutaneous obesity on HFD, whereas cre+ animals develop visceral obesity (Fig. 1C; Supp. Fig. 1E). Cre+ mice on SD also have a more pronounced visceral fat mass bias, but total fat mass, lean mass and body weight are unaffected (Fig. 1C-F; Supp. Fig. 1E). Cre- males fed a HFD have greater body weight (Fig. 1D) and fat mass (Fig. 1F) than cre+ males but have the same amount of lean mass (Fig. diminished mesenteric and anterior subcutaneous fat (Supp. Fig. 1B). It is unclear why mesenteric fat mass is reduced in these mice. However, lineage tracing has shown that Prx1-cre labels a subset of anterior subcutaneous adipocytes (Sanchez-Gurmaches et al., 2015) which could explain the partial reduction in size of this depot. Similar to males, female cre+ mice do not accrue inguinal fat in obesity (Supp. Fig. 1E) yet have a more modest reduction in total fat mass compared to cre- counterparts (Fig. 1F). Brown adipose tissue mass is unaffected in cre+ animals of both sexes (Supp. Fig. 1B, D). These data show that knocking out PPARy in the Prx1 expression domain results in reduced subcutaneous fat mass while the total quantity of visceral fat in cre+ and cre- mice is similar (Fig. 1B. ;Supp. Fig. 1B-D). 
A

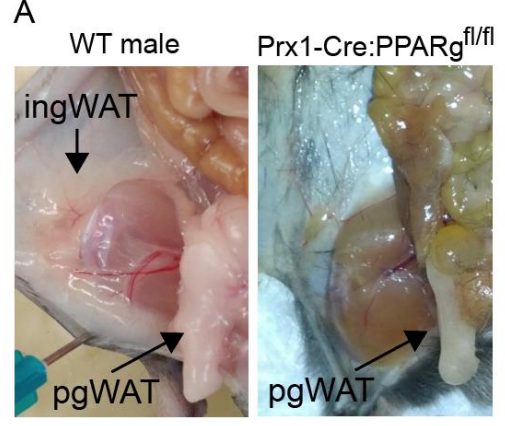

D

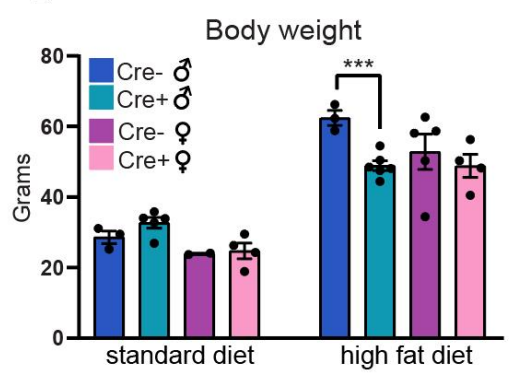

B

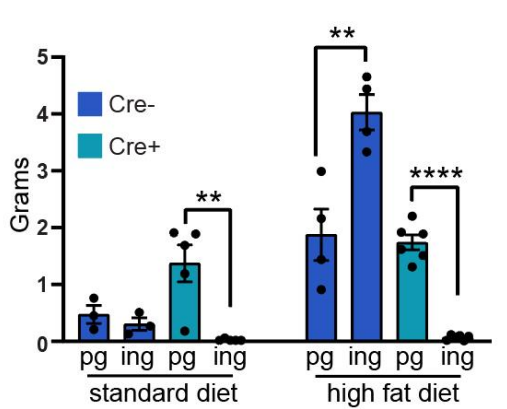

$\mathrm{E}$

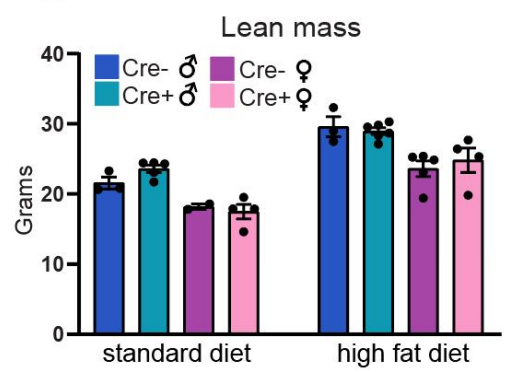

C

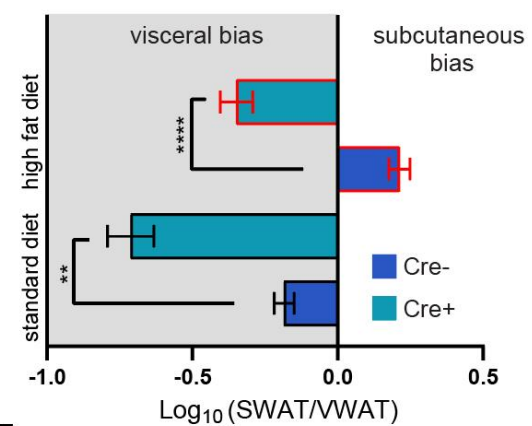

F

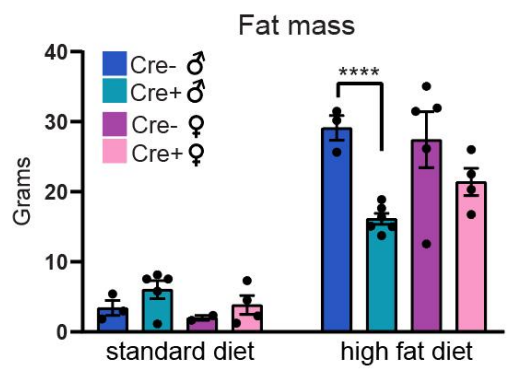

Figure 1. A visceral fat mass bias results from genetic ablation of inguinal subcutaneous fat.

(A) Images of wildtype or Prx1-Cre:PPARy/flfl male mice at 5-6 weeks of age.

(B) Perigonadal and inguinal fat depot weights in wildtype cre- males and Prx1-Cre:PPARy ${ }^{\mathrm{fl} / \mathrm{fl}}$ mice on standard diet and high fat diet $(n=4-6)$.

(C) Fat distribution of mice in (B) $(n=4-6)$.

(D) Body weight of male and female cre-/+ mice on standard diet or high fat diet ( $n=4-6$ for males; $n=2-5$ for females).

(E) Lean mass as determined by MRI of male and female cre-/+ mice on standard diet or high fat diet ( $n=4-6$ for males; $n=2-5$ for females).

(F) Fat mass as determined by MRI of male and female cre-/+ mice on standard diet or high fat diet ( $\mathrm{n}=4-6$ for males; $n=2-5$ for females).

Note: Statistical significance was determined by two-tailed Student's t-tests. Abbreviations: $p g=$ perigonadal, ing = inguinal, SWAT = subcutaneous white adipose tissue, VWAT = visceral white adipose tissue.

Next, we assessed the impact of fat distribution on glucose metabolism in these mice. 
77 tolerance is strongly associated with total fat mass (Fig. 2G), not fat distribution (Fig. 2F), this observation

78 can be accounted for by the reduced total fat mass in Prx1-Cre:PPARy ${ }^{\mathrm{fl} / \mathrm{fl}}$ males compared to cre- controls.

79 Indeed, female Prx1-Cre:PPARy/ffl mice, which have a more modest reduction in total fat mass than males

80 (Fig. 1F), do not exhibit a significant difference in glucose tolerance relative to cre- animals (Fig. 2E).

81 Therefore, genetic ablation of inguinal fat and the resulting visceral fat mass bias do not detrimentally

82 impact blood glucose regulation by the parameters assessed. Instead, it is the total quantity of fat,

83 independent of its anatomic distribution, that determines glucometabolic health in this mouse model.

A

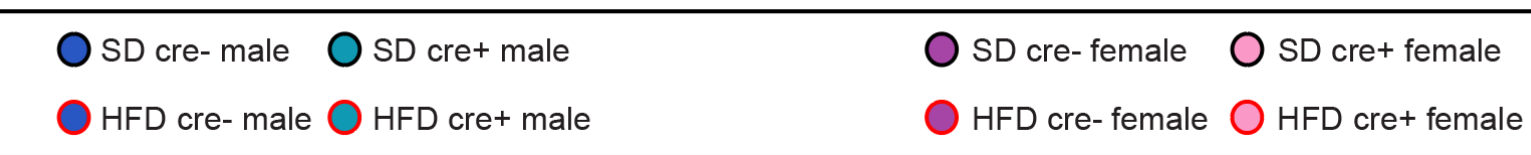

B
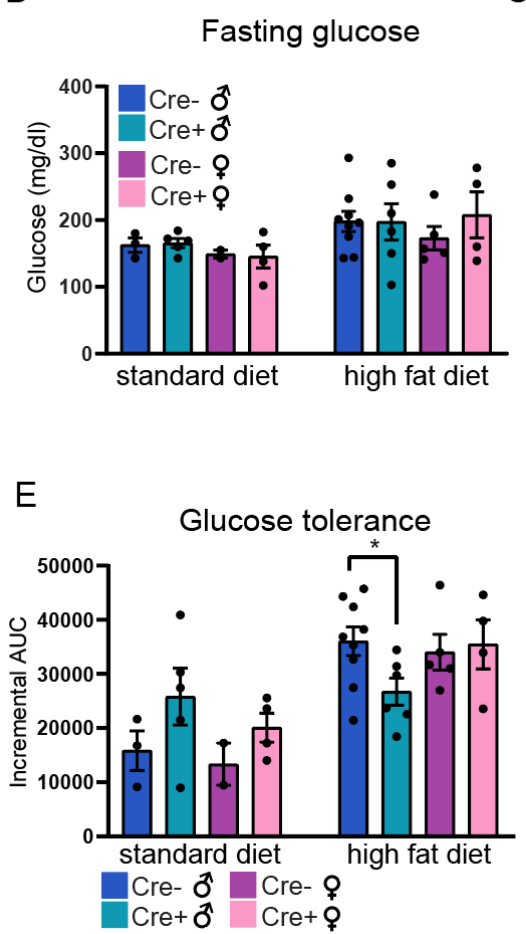

C Fat distribution vs fasting glucose

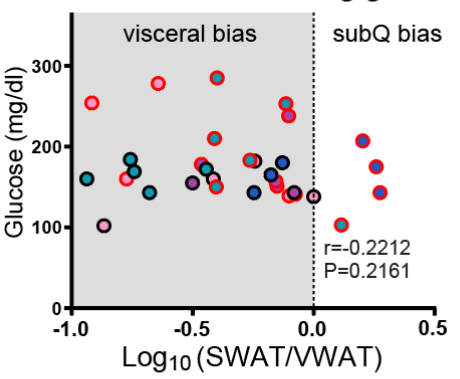

$\mathrm{F}$

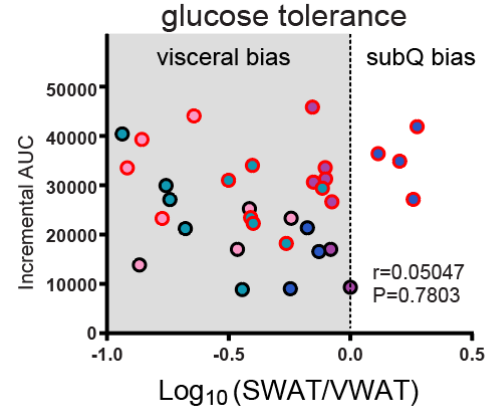

Fat mass vs fasting glucose

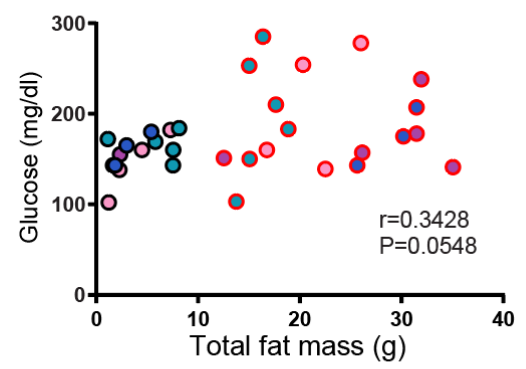

G

Fat mass vs glucose tolerance

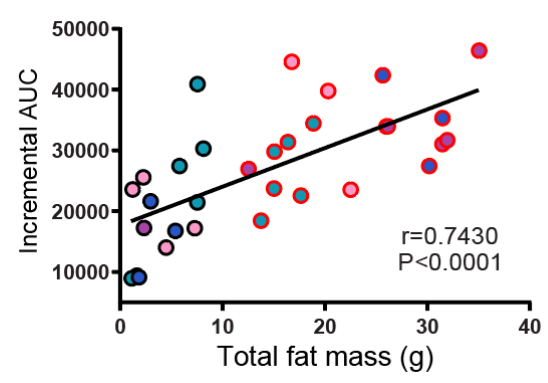


Figure 2. Inguinal fat ablation does not exacerbate obesity-associated impairments in glucose metabolism.

(A) Legend to denote genotype and diet of animals in (C), (D), (F) and (G).

(B) Fasting glucose ( $n=3-9$ for males; $n=2-5$ for females).

(C) Correlation between fasting glucose and fat distribution as expressed as the logarithm of the SWAT/VWAT ratio $(n=32)$

(D) Correlation between fasting glucose and total fat mass as determined by MRI $(n=32)$.

(E) Glucose tolerance as expressed as the incremental area under the curve ( $n=3-9$ for males; $n=2-5$ for females).

(F) Correlation between glucose tolerance and fat distribution $(n=32)$.

(G) Correlation between glucose tolerance and total fat mass $(n=32)$.

Note: Statistical significance was determined by two-tailed Student's t-tests in (B) and (E). Significance in (C), (D), (F), and (G) was determined by Spearman correlation analysis. Abbreviations: SD = standard diet, HFD = high fat diet, SWAT $=$ subcutaneous white adipose tissue, VWAT $=$ visceral white adipose tissue.

Increased subcutaneous fat in ARdY mice does not induce glucometabolic benefits in obesity

To further assess the impact of subcutaneous fat mass on glucometabolic health in obesity we

leveraged sex-specific differences in fat distribution. Females accrue a proportionally greater quantity of

87 subcutaneous fat and have higher adiponectin levels than males: features that are thought to contribute

to the reduced risk for metabolic disease in women compared to men (Cnop et al., 2003, Geer and Shen,

2009, Palmer and Clegg, 2015). Interestingly, a subcutaneous fat mass bias is known to result from deleterious mutations in the androgen receptor (AR) gene in XY humans (Boehmer et al., 2001, Gottlieb and Trifiro, 2017, Mongan et al., 2015) and recent findings indicate similar effects occur in androgen reported for $A R$ deficient $X Y$ (ARdY) mice (Fan et al., 2005). AR deficiency results in an anatomically intermediate phenotype between males and females such that mice and humans with this condition develop secondary sexual characteristics of females (including adiposity) yet lack internal reproductive structures other than small testes (Lyon and Hawkes, 1970, Boehmer et al., 2001, Gottlieb and Trifiro, 97 2017, Mongan et al., 2015). Therefore, as in previous studies with ARdY mice (Lyon and Hawkes, 1970, 
A

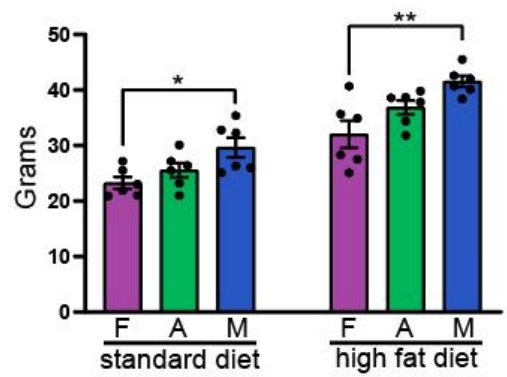

D

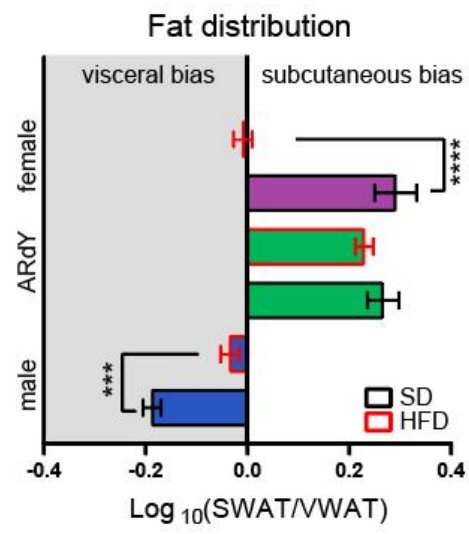

$\mathrm{F}$

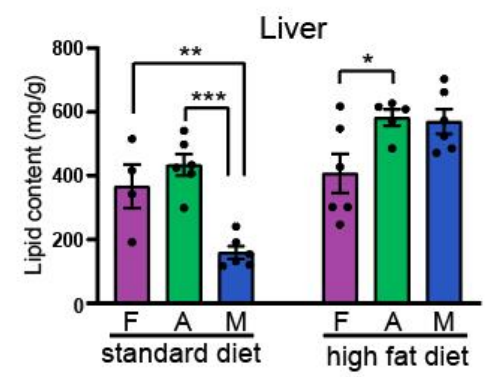

B

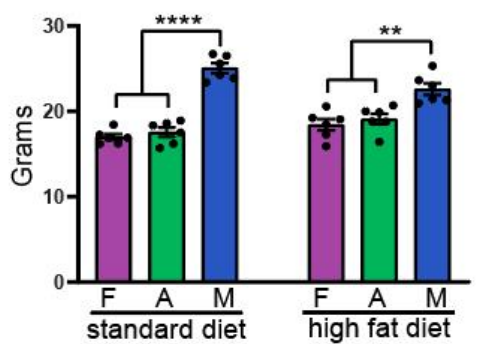

C

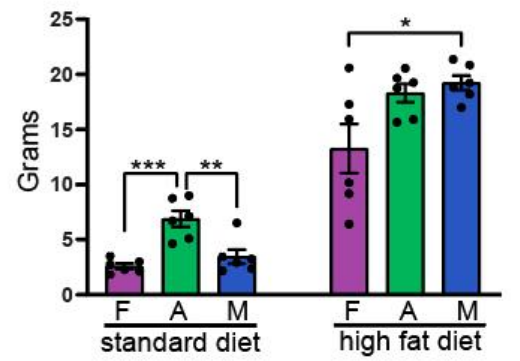

E

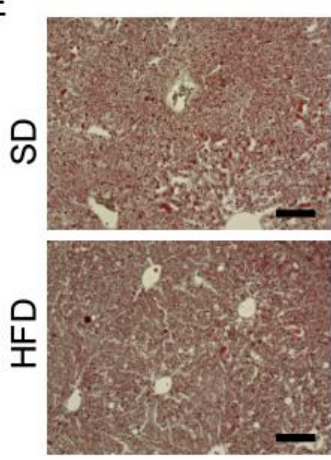

female
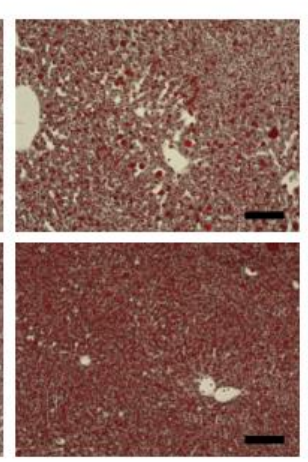

ARdY

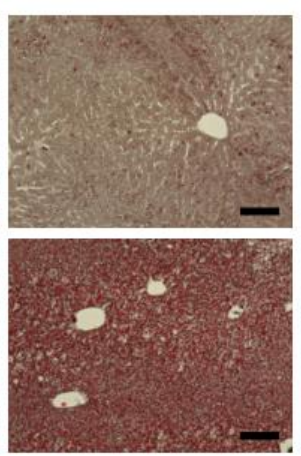

male
G

$\mathrm{H}$

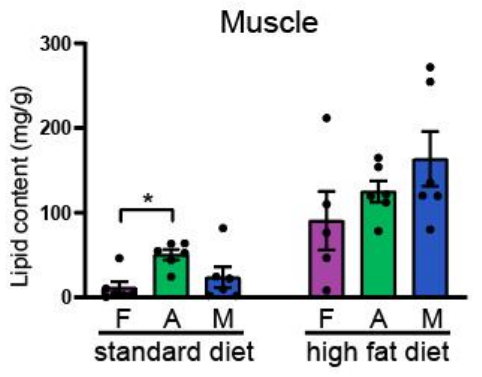

Figure 3. Subcutaneous obesity in ARdY mice does not protect from ectopic lipid deposition.

(A) Body weight in grams ( $n=6)$.

(B) Lean mass as determined by MRI $(n=6)$.

(C) Fat mass as determined by MRI $(n=6)$.

(D) Fat distribution expressed as the logarithm of subcutaneous/visceral fat mass ratio $(n=6)$.

(E) Brightfield images of oil red $O$ stained livers from mice in (A-D).

(F) Liver lipid content in mice from (A-E) $(n=4-6)$.

(G) Lipid content of gastrocnemius muscle in mice from $(A-F)(n=5-6)$

(H) Heart lipid content in mice from $(A-G)(n=6)$.

Note: Statistical significance was determined by ordinary one-way ANOVA in (A-C) and (F-H); in (D) significance was determined by a two-tailed Student's $t$-test. Scale bar in $(E)$ is 100 um. Abbreviations: $F=$ female, $A=A R d Y, M=$ male, SWAT = subcutaneous white adipose tissue, VWAT = visceral white adipose tissue, $\mathrm{SD}=$ standard diet, HFD = high fat diet 
First, we determined the impact of diet-induced obesity on body composition and fat distribution

101

102

103

104

105

106

107

108

109

110

111

112

113

114

115

116

117

in male, female and ARdY mice by feeding them either a SD or HFD for a period of 8 weeks starting at 7 weeks of age (Supp. Fig. 2B). At 15 weeks of age, under both dietary conditions, ARdY body weight is between that of males and females and ARdY lean mass is similar to females (Fig. 3A, B). In addition, brown fat weight in ARdY mice is no different from males or females on both diets (Supp. Fig. 4C). Notably, ARdY mice accumulate more total fat mass on SD than wildtype animals (Fig. 3C), consistent with previous findings that show an age-associated increase in fat mass in androgen insensitive mice (Sato et al., 2003). However, after 8 weeks of HFD, ARdY mice gain a similar amount of fat as wildtype animals (Fig. 3C). As expected, fat distribution in ARdY and female mice is biased toward subcutaneous depots, while male mice exhibit a visceral fat mass bias on SD (Fig. 3D). Plasma adiponectin is positively associated with subcutaneous adiposity and this is driven by the comparatively reduced adiponectin in male mice (Supp. Fig. 2C), a finding consistent with previous observations in humans (Cnop et al., 2003). Importantly, on HFD, ARdY mice preferentially accrue subcutaneous fat and wildtype animals develop a neutral fat distribution (Fig. 3D, Supp. Fig. 2D). Since high adiponectin activity has been shown to drive the preferential accumulation of subcutaneous fat in obesity (Kim et al., 2007), we compared plasma adiponectin levels in lean and obese ARdY mice. We found that plasma adiponectin is reduced in obese ARdY mice (Supp. Fig. 2E), indicating adiponectin activity does not drive the preferential deposition of subcutaneous fat in these animals.

Given that subcutaneous obesity is thought to protect from ectopic lipid deposition, we quantified the lipid content of liver, gastrocnemius muscle and heart in ARdY mice and controls. Surprisingly, ectopic lipid deposition in the livers of $A R d Y$ mice, as assessed by oil red $O$ staining, is not improved relative to wildtype animals on SD or HFD (Fig. 3E). Consistent with the oil red O staining, a direct quantitation of lipid content in the liver, gastrocnemius and heart show no improvement in ARdY mice relative to animals with similar fat mass (Fig. 3E-H). Indeed, fat distribution does not correlate with ectopic lipid deposition 
A

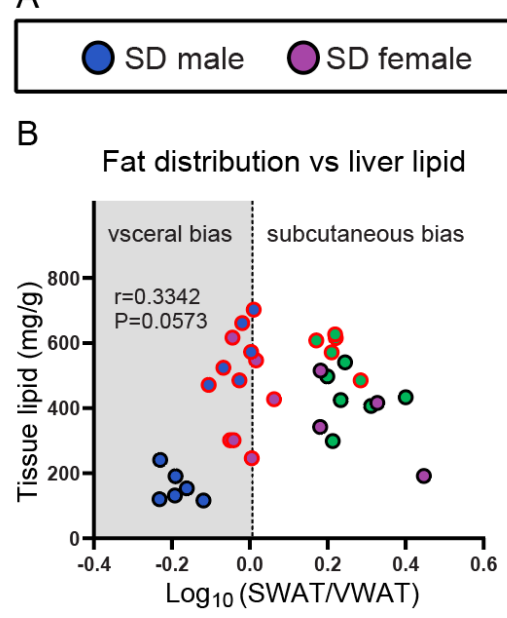

E

Fat mass vs liver lipid

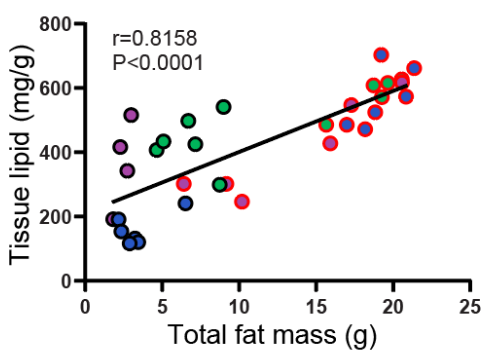

C

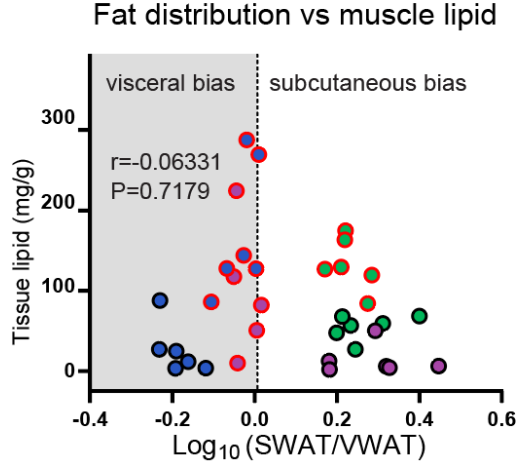

$\mathrm{F}$

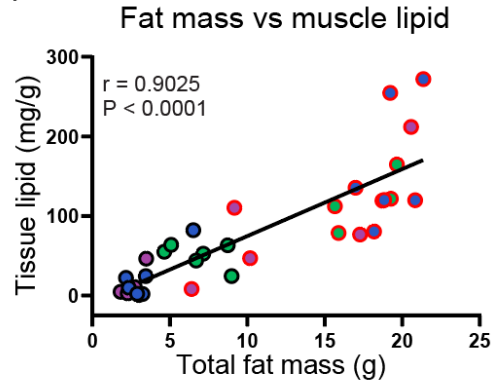

HFD female

HFD ARdY

D

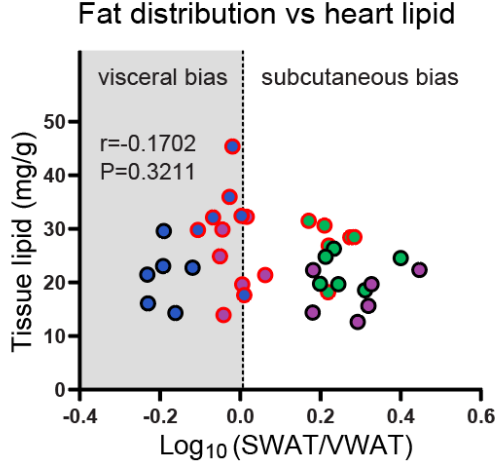

G

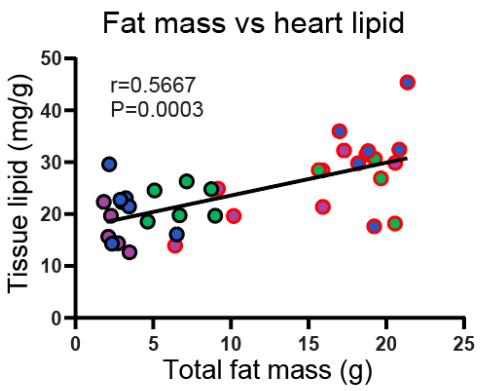

Figure 4. Total fat mass, not fat distribution, predicts ectopic lipid deposition in peripheral organs.

(A) Legend denoting mouse genotype and diet.

(B) Correlation between liver lipid content and fat distribution.

(C) Correlation between gastrocnemius muscle lipid content and fat distribution.

(D) Correlation between heart lipid content and fat distribution.

(E) Correlation between liver lipid content and total fat mass as determined by MRI.

(F) Correlation between gastrocnemius muscle lipid content and total fat mass as determined by MRI.

(G) Correlation between heart lipid content and total fat mass as determined by MRI.

Note: each dot represents a single animal for which tissue lipid content, total fat mass and fat distribution were determined ( $n=33-36$ for each plot). Statistical significance was determined by Spearman's correlation analysis.

We also characterized diabetic phenotypes in these animals by performing glucose tolerance tests 
SD (Fig. 5A, D), probably due to increased fat mass (Fig. 3C). Consistent with this, total fat mass is an

131 effective predictor of fasting glucose and glucose tolerance (Fig. 5D, G), as is ectopic lipid deposition (Supp.

132 Fig. 3B-G). Fat distribution and total lean mass, on the other hand, do not correlate with either parameter

A

$$
\text { OSD male OSD female OSD ARdY HFD male } \bigcirc \text { HFD female } \bigcirc \text { HFD ARdY }
$$

B

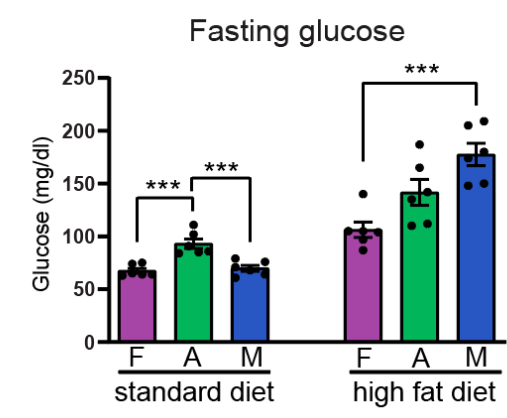

$E$

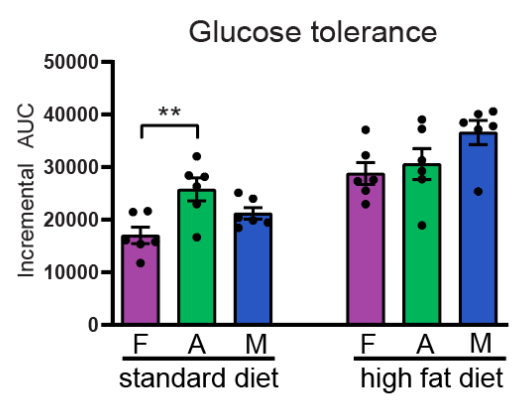

C Fat distribution vs fasting glucose

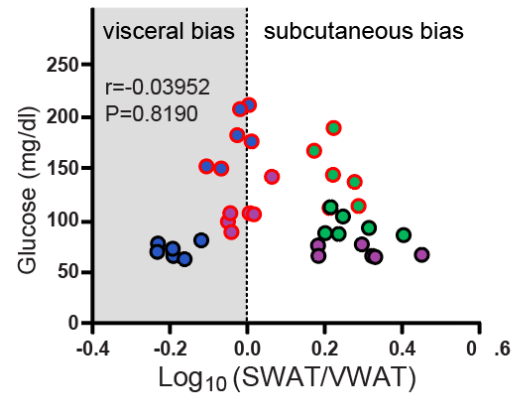

$\mathrm{F}$

Fat distribution vs glucose tolerance

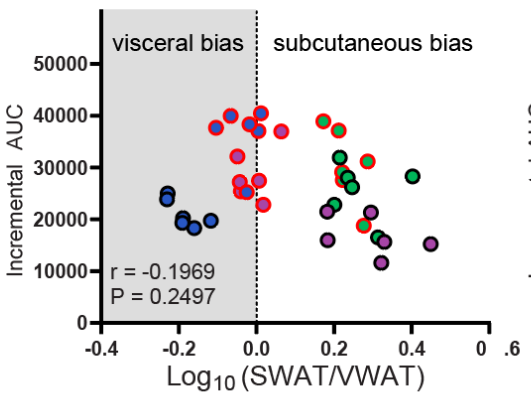

Fat mass vs fasting glucose

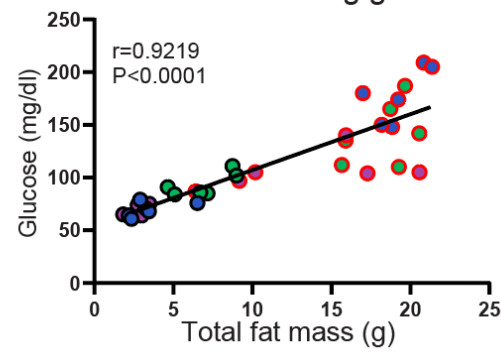

G

Fat mass vs glucose tolerance

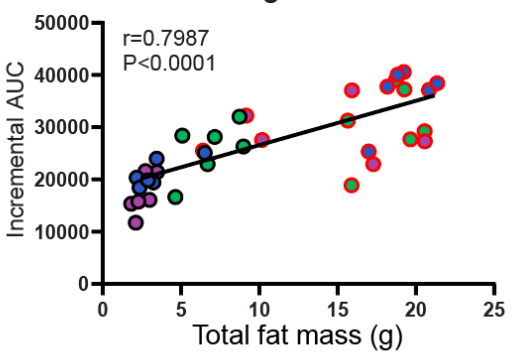

Figure 5. Total fat mass, not fat distribution, predicts glucometabolic health.

(A) Legend denoting mouse genotype and diet.

(B) Fasting glucose in 15-week-old female, ARdY and male mice on standard diet and high fat diet.

(C) Correlation between fat distribution and fasting glucose.

(D) Correlation between total fat mass as determined by MRI and fasting glucose.

(E) Glucose tolerance expressed as incremental area under the curve.

(F) Correlation between fat distribution and glucose tolerance.

(G) Correlation between total fat mass as determined by MRI and glucose tolerance. 
Figure 5 legend continued.

Note: each dot represents a single animal for which fasting glucose and glucose tolerance were determined $(n=36$ for each plot). Glucose tolerance is quantitated as the incremental area under the curve. Abbreviations: $F=$ female, $A=$ ARdY, $M=$ male, SWAT = subcutaneous white adipose tissue, VWAT = visceral white adipose tissue, $S D=$ standard diet, $\mathrm{HFD}=$ high fat diet, $A U C=$ area under the curve. Statistical significance in (B) and (E) was determined ordinary one-way ANOVA. Statistical significance in (C), (D), (F), and (G) was determined by Spearman correlation analysis.

with ARdY values directly in between (Fig. 5B). The improved fasting glucose in females is not due to

Fig. 2J). These data corroborate prior studies that link improved glucose metabolism to adiponectin activity in obesity but also show that fat distribution is separable from these phenomena. number of adipocytes in this depot. 
157 in mice (Holtrup et al., 2017). However, we found no difference in adipocyte precursor proliferation (a

158 prerequisite to adipogenesis) between these depots from P20-P25 in ARdY mice (Fig. 6F), suggesting this

159 developmental period does not impact fat distribution in these animals. Indeed, at P18, which is prior to

160 the outset of puberty, ARdY mice exhibit a subcutaneous fat mass bias significantly greater than males

161 and females (Fig. 6G). By directly comparing perigonadal and inguinal fat weights we found that the

162 perigonadal depot is smaller in ARdY mice compared to males and females at this age, with no differences

163 in inguinal fat weights (Fig. 6H). This indicates the subcutaneous fat mass bias in ARdY mice is due to a

164 defect in perigonadal fat development. Therefore, we quantified adipocyte formation from E18.5 to P18

165 (Supp. Fig. 4H) and P4 to P18 (Fig. 6I) to identify if adipogenesis is impeded in ARdY perigonadal fat at

these developmental timepoints. Surprisingly, no differences in adipocyte formation were observed between males, females and ARdY mice in either perigonadal or inguinal fat depots, indicating differential adipogenesis rates between depots does not control ARdY fat distribution.

Another factor that can impact fat mass is the total number of adipocyte precursors available to

171 pool such that, even with a normal rate of adipogenesis, fewer adipocytes ultimately form. Consistent

172 with this hypothesis, ARdY mice between 18 and 21 days of age have fewer perigonadal adipocyte

173 precursors (Fig. 6J) and total stromal vascular cells (Supp. Fig. 4F, G) than males of the same age.

174 Moreover, it has been shown that male perigonadal fat arises from a transient structure called the 175 "epididymal appendage" which serves as a progenitor field for the nascent fat depot (Han et al., 2011).

176 Strikingly, the epididymal appendage is completely absent in ARdY mice (Fig. 6K). Therefore, the 177 subcutaneous fat mass bias in ARdY mice is due to a dramatic reduction in perigonadal adipocyte 178 precursor seeding that results in impaired perigonadal fat expansion. These results indicate that the size 179 of the adipocyte precursor pool in nascent adipose tissue is a critical determinant of adult fat depot mass. 
A
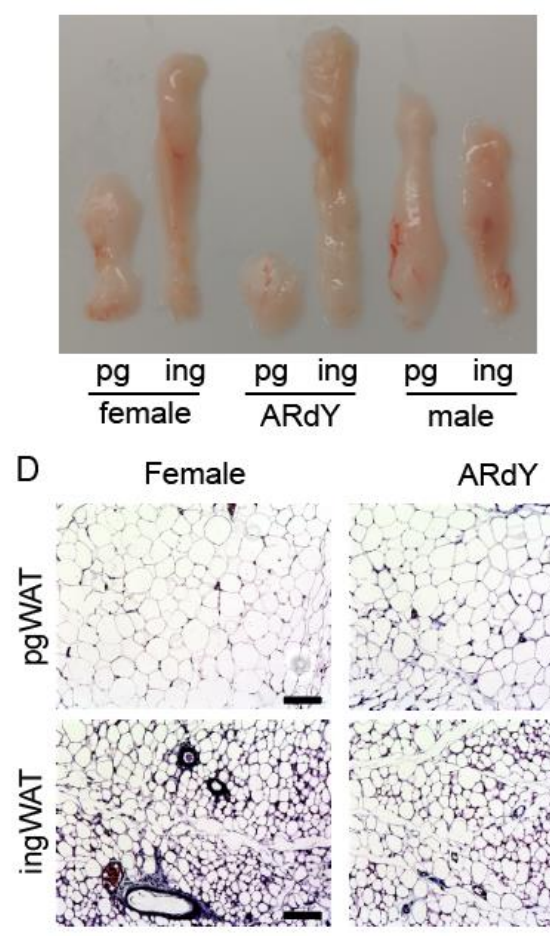

$\mathrm{F}$
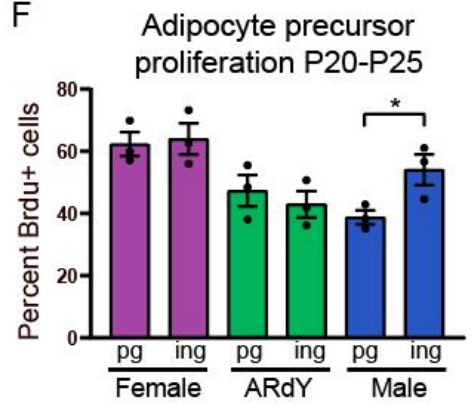

I

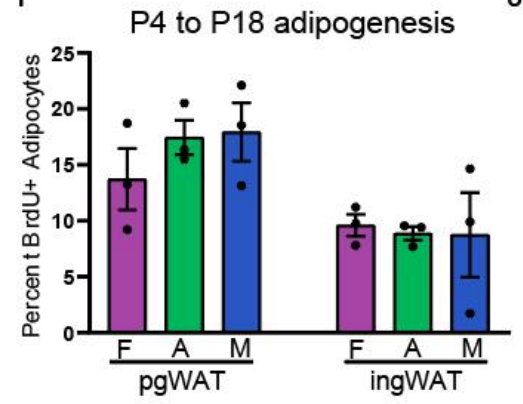

ARdY

$\mathrm{J}$
B

Depot weights
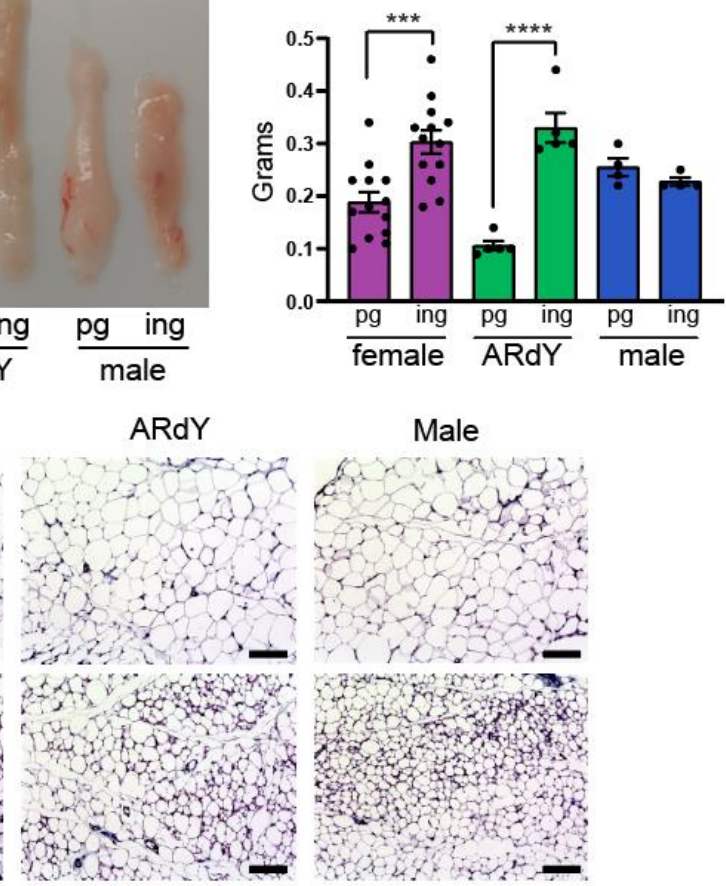

G
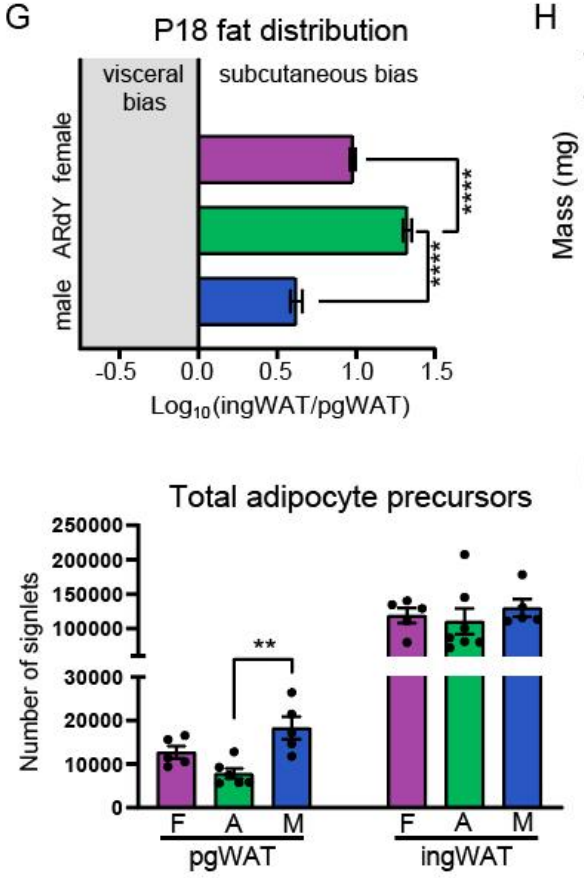

C Fat distribution

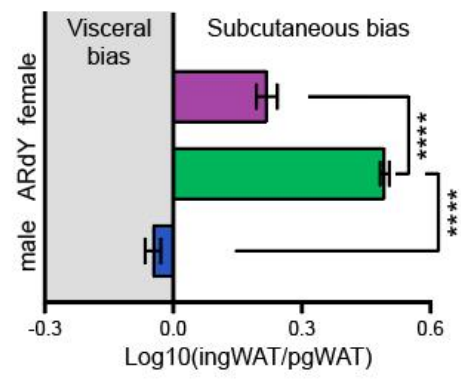

E

Adipocyte size

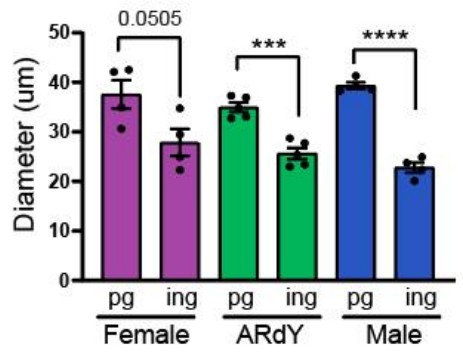

H P18 depot weights

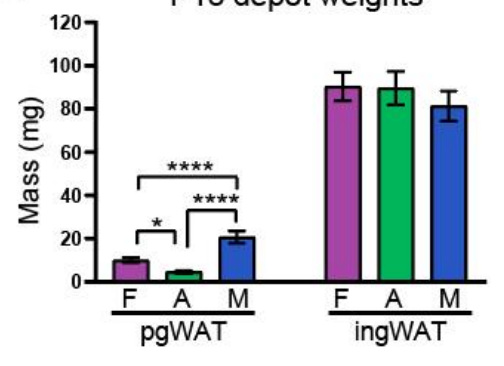

$\mathrm{K}$

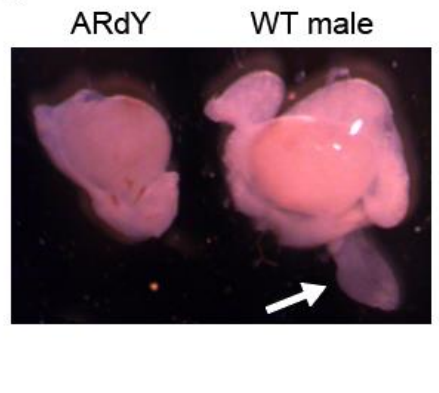

Figure 6. ARdY mice have a subcutaneous fat mass bias due to reduced perigonadal adipocyte precursor seeding.

(A) Perigonadal and inguinal fat depots in 7-week-old female, ARdY and male mice.

(B) Fat depot weights from (A) $(n=4-13)$.

(C) Fat distribution expressed as the logarithm of ingWAT/pgWAT fat mass ratio ( $n=4-13$ ).

(D) Trichrome stained histological sections of adipose tissue (scalebar $=100 \mathrm{um}$ ).

(E) Adipocyte size quantification expressed as diameter $(n=4-5)$. Legend continued on next page. 
Figure 6 legend continued.

(F) Percentage of proliferative adipocyte precursors from P20-P25 as quantified by bromodeoxyuridine (BrdU) incorporation (cells were pooled from two animals for each genotype: technical replicates $=3$, biological replicates $=6$ ).

(G) Fat distribution in P18 animals as expressed as the logarithm of the inguinal/perigonadal fat mass ratio ( $n=12-24)$.

(H) Perigonadal and inguinal fat depot weights of P18 animals ( $n=12-24)$.

(I) Adipocyte formation from P4-P18 as determined by BrdU pulse-chase (n-3).

(J) Total number of adipocyte precursors from perigonadal and inguinal fat depots of 18-21-day old mice ( $n=5-7)$

(K) Image of testis, epididymis and epididymal appendage of ARdY and male mice at P4. Epididymal appendage is denoted by the white arrow.

Note: statistical significance was determined by unpaired two-tailed Students t-tests in (B), (E) and (F). Significance in (C) and (G-J) by ordinary one-way ANOVA with Tukey's multiple comparison's test. Abbreviations: $\mathrm{pg}=$ perigonadal, ing = inguinal, SWAT = subcutaneous white adipose tissue, VWAT $=$ visceral white adipose tissue, $F=$ female, $A=A R d Y, M=$ male.

\section{Discussion}

This is surprising given that fat distribution is typically an effective predictor of metabolic health, but is 
probably one such factor given its well-documented association with subcutaneous adiposity and

197 improved metabolism (Kim et al., 2007, Aguilar-Salinas et al., 2008, Buemann et al., 2006, Buemann et al.,

198 2005). Understanding the thresholds at which adiponectin promotes proper glucose regulation and subctaneous fat mass, as well as the interdependence of fat mass and adiponectin production will be important areas of future work.

The role of sex hormones in biased fat accumulation and metabolic health is also a major area of research interest (Palmer and Clegg, 2015). However, little attention has been given to the effect of these molecules on fat distribution prior to puberty. The observation that ARdY mice have impaired perigonadal fat development is intriguing given the embryonic patterning of perigonadal fat is distinct in males and signaling is required not only for the proper establishment of male gonads, but for the embryonic patterning of murine perigonadal fat as well. Further work will be necessary to determine if this is the the unique effects of individual genes, dietary components and other parameters associated with fat distribution may reveal specific drivers for the metabolic effects typically linked to visceral and

215 subcutaneous obesity.

\section{Materials and Methods}

\section{Animals and assessment of fat distribution}

218 Animal experiments were performed according to Yale University's Institutional Animal Care and Use 219 Committee (IACUC). ARdY mice (Lyon and Hawkes, 1970) were obtained from Jackson Laboratories (Stock 


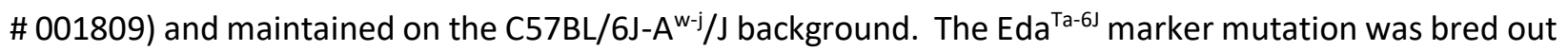
of the strain prior to experiments. Prx1-Cre (Stock \# 005584) (Logan et al., 2002) and PPARy ${ }^{\mathrm{fl} / \mathrm{fl}}$ (Stock \# 004584) (He et al., 2003) mice were bred to generate Prx1-Cre:PPARy $y^{f / f l}$ mice that lack inguinal fat. Standard diet in this study was made by Harlan Laboratories (2018S) and high fat diet by Research Diets (D12492). Body composition of mice was determined via magnetic resonance imaging (EchoMRI-100H, EchoMRI, Houston, TX, USA).

Fat distribution was calculated using the following equation,

$$
\log 10\left(\frac{i n g W A T+a s W A T}{p g W A T+m W A T+r W A T}\right)
$$

where the weight in grams of each subcutaneous (ingWAT and asWAT) and visceral (pgWAT, mWAT and rWAT) depot were combined and divided to acquire an SWAT/VWAT ratio. The logarithm of this ratio is required to correct for skew. Notably, "inguinal fat" in this study refers to the continuous adipose depot that runs along the dorsolumbar-gluteal axis of the hindlimb in mice. Only white adipose depot weights were included in the fat distribution calculation.

\section{Adipocyte hyperplasia and hypertrophy}

Quantification of adipocyte precursor proliferation and adipocyte formation was performed as described previously (Jeffery et al., 2015, Berry and Rodeheffer, 2013). Briefly, to quantify adipocyte formation from E18.5 to P18, pregnant dams were injected intraperitoneally with $50 \mathrm{mg} / \mathrm{kg} \mathrm{BrdU}$ in PBS. Adipocyte nuclei from pups of such litters were analyzed for BrdU incorporation at P18. Similarly, to quantify adipocyte formation from P4-P18, P4 pups were injected intraperitoneally with 50mg/kg BrdU in PBS in the morning and evening and allowed to develop until P18, at which point BrdU incorporation into adipocyte nuclei was quantified. At least $100 \mathrm{BrdU}+$ adipocytes were counted for each depot. Adipocyte size was determined from images of trichrome-stained histological sections of adipose tissue using Cell Profiler (Carpenter et al., 2006). Histological sectioning and trichrome staining was performed by the Histology 
242 Core Laboratory of the Yale School of Medicine, Department of Comparative Medicine. Images were

243 taken using a Leica SP5 confocal microscope for the quantification of BrdU+ adipocyte nuclei and a

244 Keyence BZ-X800 microscope for adipocyte sizing.

245 Glucose tolerance tests and lipid quantification

246 Mice were fasted overnight (16-18 h) and fasting blood glucose level was obtained via a tail vein nick.

247 Mice were injected intraperitoneally with a $20 \%$ glucose solution in saline at $2 \mathrm{~g} / \mathrm{g} / \mathrm{ucose} / \mathrm{kg}$ body weight

248 and blood glucose was measured at 10, 20, 30, 60 and 120 minutes afterward. Glucose tolerance is 249 defined as the incremental area under the curve (i.e. the area under the curve normalized to fasting 250 glucose). Tissue lipid quantification in liver, gastrocnemius and heart was performed using the Cell Biolabs

251 Fluorometric Lipid Quantification Kit (Catalog \# STA-617) according to manufacturer's instructions with 252 reagent volumes halved in technical singlicate. For Oil Red O staining, the medial lobe of the liver was 253 fixed in $4 \%$ paraformaldehyde for $\sim 24 \mathrm{~h}$ followed by incubation in $30 \%$ sucrose in saline for $\sim 24 \mathrm{~h}$. Livers 254 were then embedded in OCT compound (Tissue-Tek, product code 4583) and flash frozen in liquid 255 nitrogen. Histological sectioning and Oil Red O staining was performed by the Histology Core Laboratory 256 of the Yale School of Medicine, Department of Comparative Medicine. Brightfield images of histological 257 sections were taken using a Keyence BZ-X800 microscope.

\section{Statistical Analysis}

Statistical tests were performed using GraphPad Prism (version 8.3.0). P-values $<0.05$ were considered significant. Specific statistical tests used for each experiment and the number of biological replicates are denoted in figure legends. Error bars represent mean \pm SEM. ${ }^{*} P<0.05,{ }^{* *} P<0.01,{ }^{* * *} \mathrm{P}<0.001$, $* * * * \mathrm{P}<0.0001$. Lines of best fit are shown only on plots with statistically significant correlations.

264 The authors thank Michael Schadt and the Histology Core Laboratory for assistance with tissue sectioning and staining. We also thank Caroline Zeiss for sharing microscopy equipment and the Yale Flow Cytometry 
bioRxiv preprint doi: https://doi.org/10.1101/2020.08 07 239665' this version posted August 7, 2020. The copyright holder for this preprint (which was not certified by peer review) is the author/funder, who has granted bioRxiv a license to display the preprint in perpetuity. It is made available under aCC-BY-NC-ND 4.0 International license.

266 Core for equipment usage. This work was supported by a National Science Foundation Graduate Research

267 Fellowship (DGE1122492 to Z.L.S.) and the NIDDK (R01DK110147 and DK090489 to M.S.R.).

268 Competing Interests

269 The authors declare no competing interests. 


\section{Supplementary Figures}

A

\begin{tabular}{|ll|}
\hline O SD cre- male $O$ SD cre+ male & $\bigcirc$ SD cre- female $\bigcirc$ SD cre+ female \\
HFD cre- male $\bigcirc$ HFD cre+male & $\bigcirc$ HFD cre-female $\bigcirc$ HFD cre+female \\
\hline
\end{tabular}

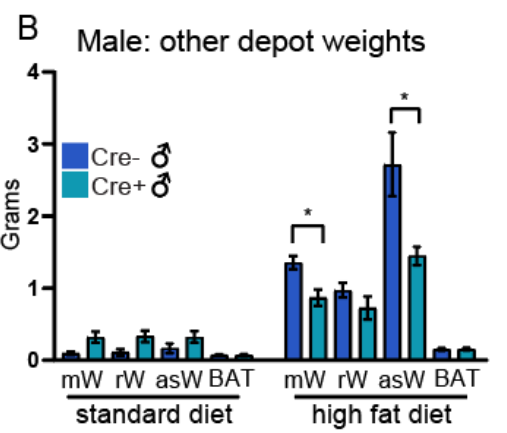

E

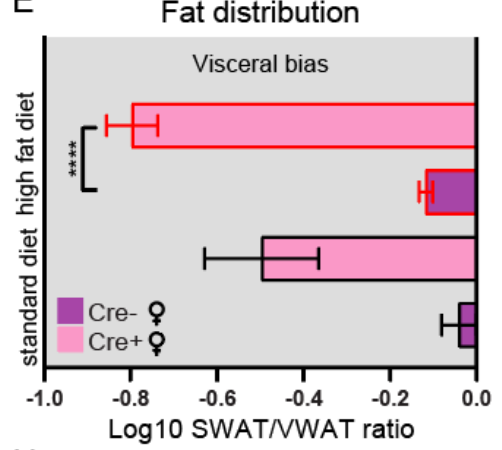

$\mathrm{H}$

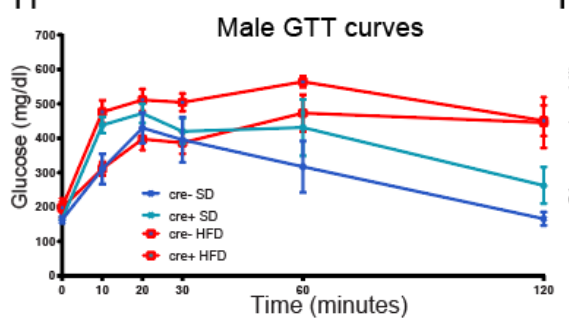

C Female pgWAT and ingWAT weights

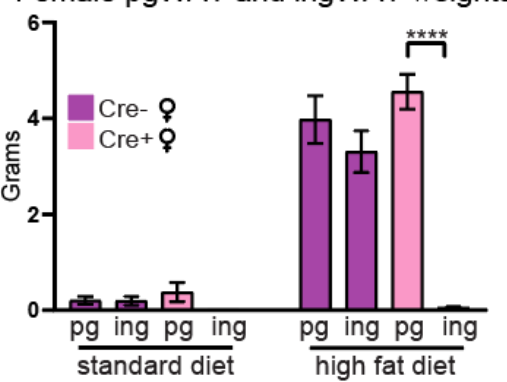

$\mathrm{F}$

Lean mass vs fasting glucose

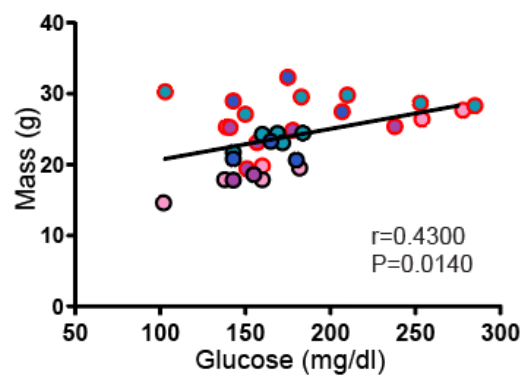

I

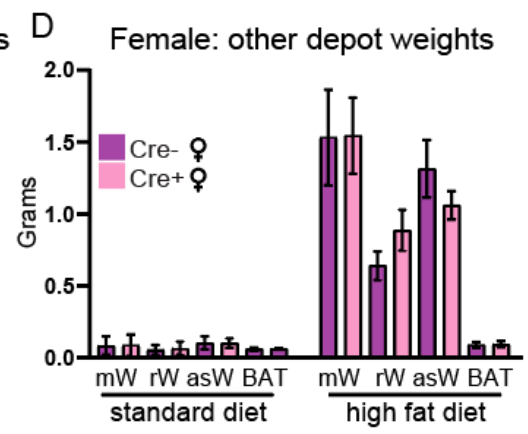

G

Lean mass vs glucose tolerance

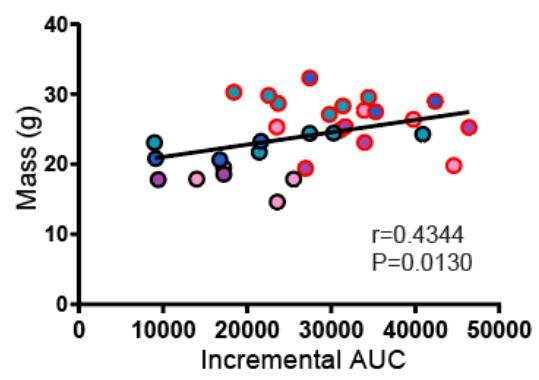

$J$

Supplementary Figure 1. Additional fat distribution and glucose metabolism parameters in Prx1-Cre:PPARy ${ }^{\mathrm{fl} / f l}$ mice.

(A) Legend to denote the genotype and diet of each animal in (F) and (G).

(B) Fat depot weights of male mice not shown in Figure 1B.

(C) Perigonadal and inguinal fat weights in female mice $(n=2-5)$

(D) Fat depot weights of female mice not shown in (C) $(n=2-5)$.

(E) Fat distribution of female mice $(n=2-5)$.

(F) Correlation between total lean mass and fasting glucose $(n=32)$.

(G) Correlation between total lean mass and glucose tolerance $(n=32)$.

(H) Glucose tolerance test of male mice fed HFD or SD ( $n=3-9)$.

(I) Glucose tolerance test of female mice fed HFD or SD ( $n=2-5)$.

(J) Schematic showing visceral and subcutaneous fat depots in mice.

Note: Statistical significance was determined by two-tailed Student's t-tests in (B), (C) and (E) and by Spearman correlation analysis in (F) and (G). 
A

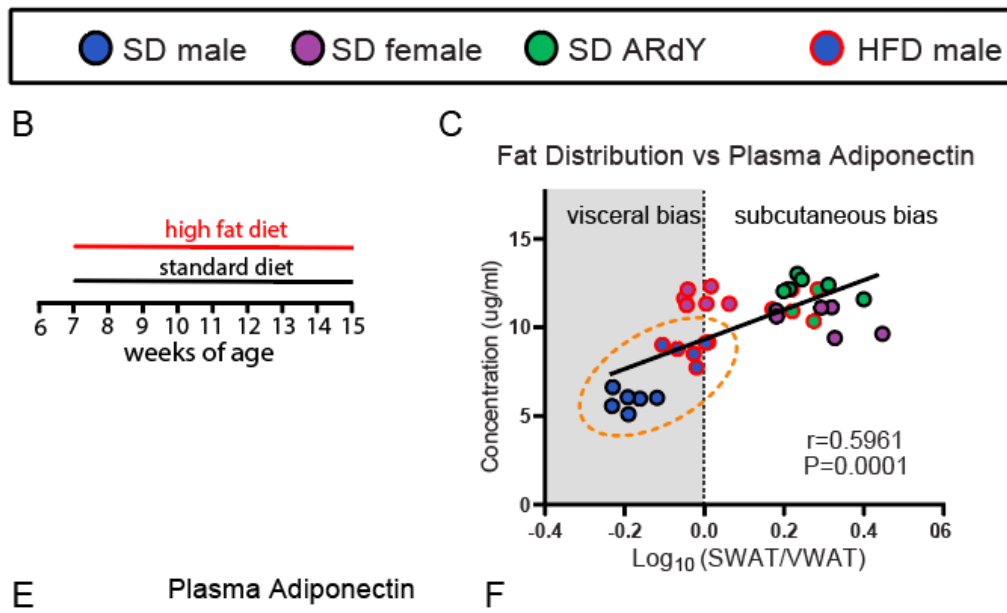

$\mathrm{E}$
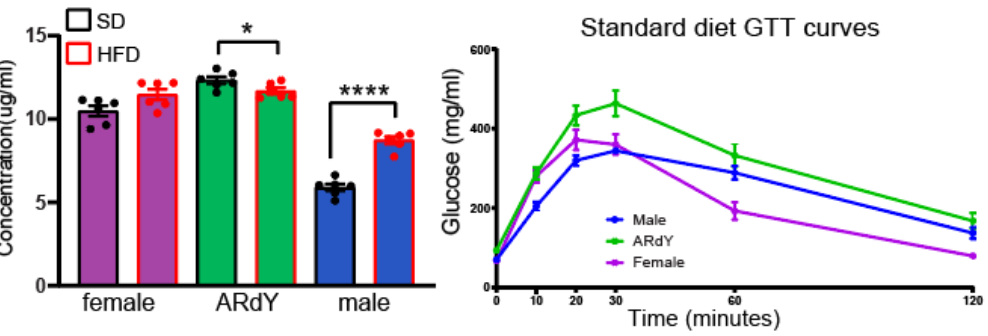

G

HFD female $O$ HFD ARdY
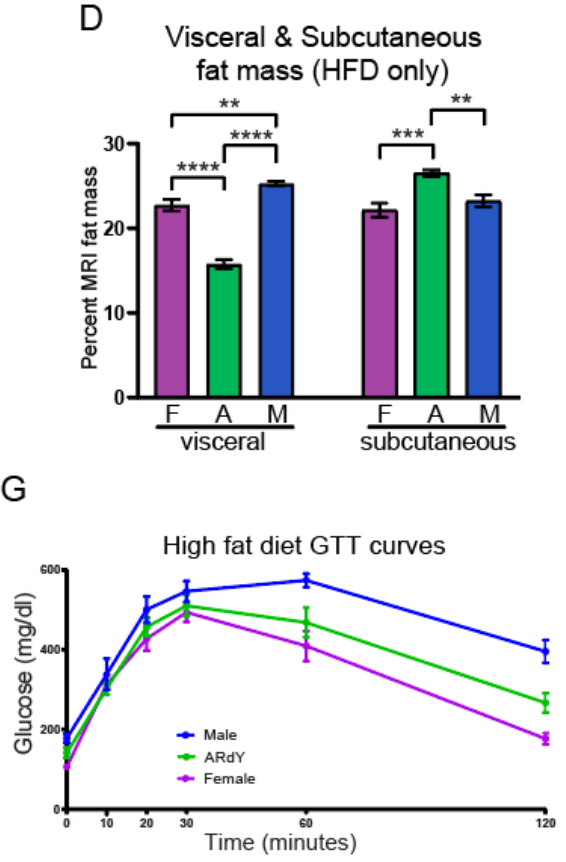

$\mathrm{H}$

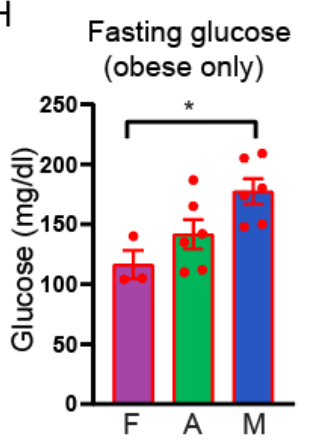

I

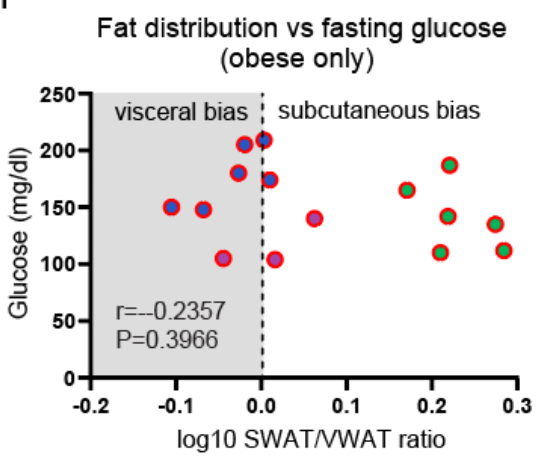

$\mathrm{J}$

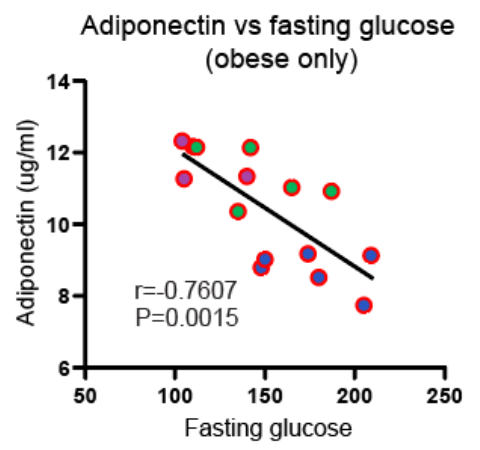

Supplementary Figure 2. Relationships between fat distribution, adiponectin and glucose metabolism.

(A) Legend to denote the genotype and diet of each animal in (C), (I) and (J).

(B) Schematic showing dietary regime for male, female and ARdY mice.

(C) Correlation between fat distribution and plasma adiponectin level $(n=35)$.

(D) Visceral and subcutaneous fat mass expressed as a percentage of total fat mass measured by MRI $(n=6)$.

(E) Plasma adiponectin level $(n=6)$.

(F) Glucose tolerance test of 15-week-old male, female, and ARdY mice fed standard diet $(n=6)$.

(G) Glucose tolerance test of 15-week-old male, female, and ARdY mice fed high fat diet $(n=6)$.

(H) Fasting glucose in mice with at least $15 \mathrm{~g}$ total fat mass $(n=3-6)$.

(I) Correlation between fat distribution and fasting glucose in obese mice $(n=14)$.

(J) Correlation between plasma adiponectin and fasting glucose in obese mice $(n=14)$.

Note: Statistical significance in (B), (I) and (J) was determined using Spearman's correlation analysis. In (D) and (H) by an ordinary one-way ANOVA with Tukey's multiple comparison's test and in (E) by a two-tailed Student's t-test. 
A

\section{SD male OSD female OSD ARdY \\ HFD male \\ HFD female \\ HFD ARdY}

B

Liver lipid vs fasting glucose

C Muscle lipid vs fasting glucose
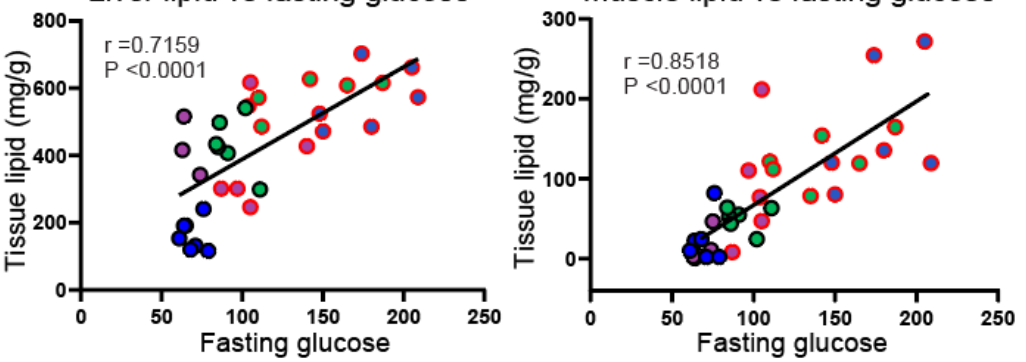

D Heart lipid vs fasting glucose

E

$F$

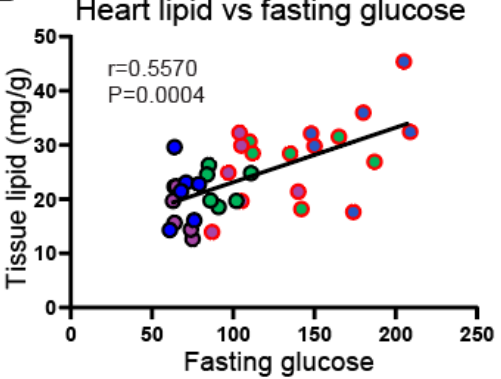

Liver lipid vs glucose tolerance

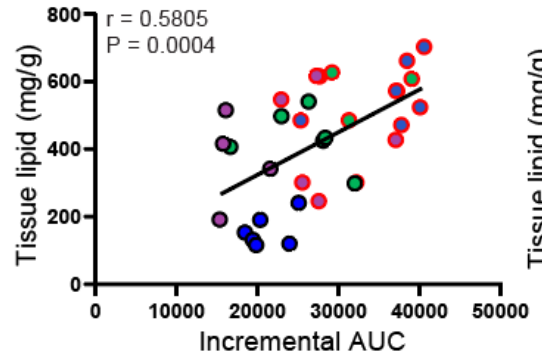

Muscle lipid vs glucose tolerance

G
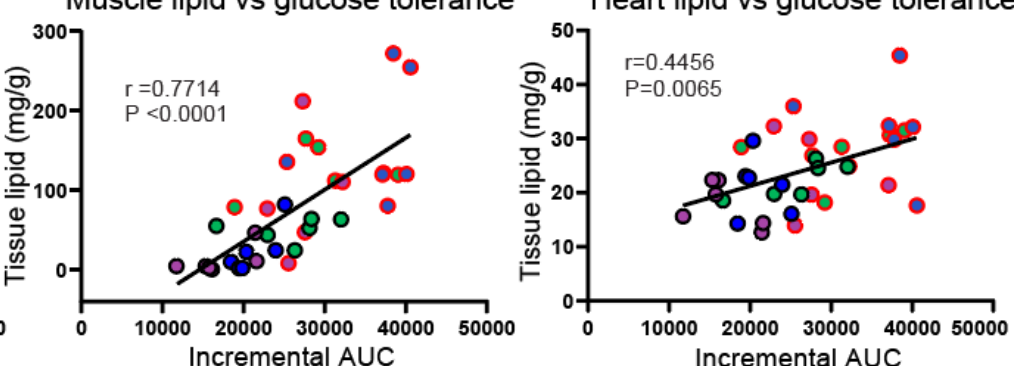

$\mathrm{H}$

VWAT mass vs fasting glucose $\mathrm{J}$

SWAT mass vs fasting glucose
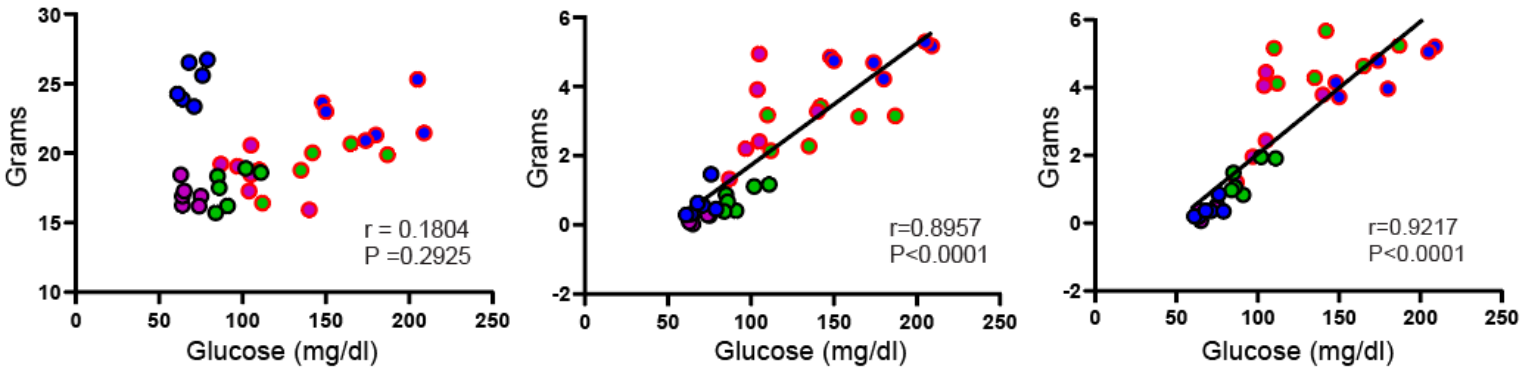

$\mathrm{K}$

$\mathrm{L}$

Lean mass vs glucose tolerance
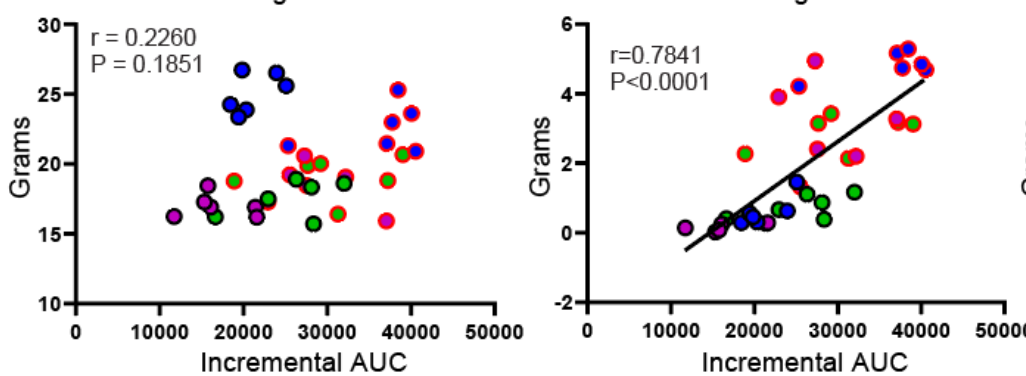

M

SWAT mass vs glucose tolerance

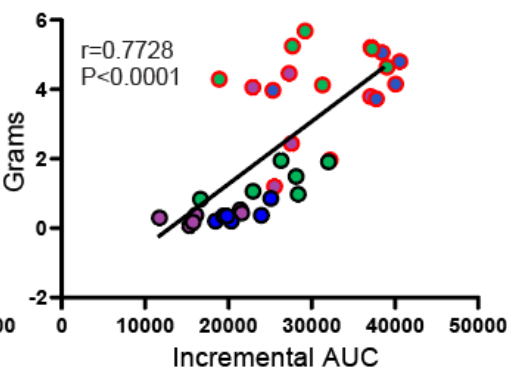

Supplementary Figure 3. Ectopic lipid deposition and fat mass predict impaired fasting glucose and glucose tolerance.

(A) Legend to denote the genotype and diet of each animal in (B-M).

(B) Correlation between liver lipid content and fasting glucose $(n=33)$.

(C) Correlation between muscle lipid content and fasting glucose $(n=34)$.

(D) Correlation between heart lipid content and fasting glucose $(n=36)$.

(E) Correlation between liver lipid content and glucose tolerance $(n=33)$.

(F) Correlation between muscle lipid content and glucose tolerance $(n=34)$.

(G) Correlation between heart lipid content and glucose tolerance $(n=36)$. Legend continued on next page 
bioRxiv preprint doi: https://doi.org/10.1101/2020.08.07.239665; this version posted August 7, 2020. The copyright holder for this preprint (which was not certified by peer review) is the author/funder, who has granted bioRxiv a license to display the preprint in perpetuity. It is made available under aCC-BY-NC-ND 4.0 International license.

Legend continued from Supplementary Figure 3.

(H) Correlation between total lean mass and fasting glucose $(n=36)$.

(I) Correlation between VWAT mass and fasting glucose $(n=36)$.

(J) Correlation between SWAT and fasting glucose ( $n=36)$.

(K) Correlation between total lean mass and glucose tolerance $(n=36)$.

(L) Correlation between VWAT mass and glucose tolerance $(n=36)$.

(M) Correlation between SWAT mass and glucose tolerance $(n=36)$.

Note: Statistical significance was determined using Spearman correlation analysis. 
A

Standard diet depot weights

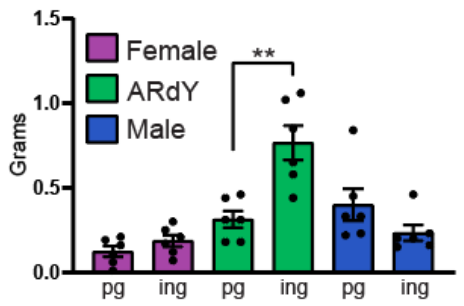

B

High fat diet depot weights

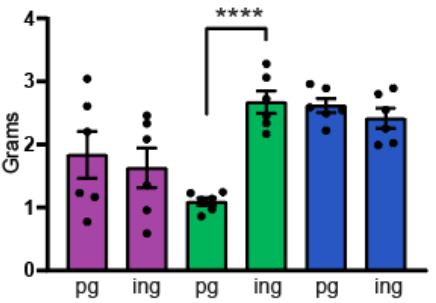

C Brown adipose weights

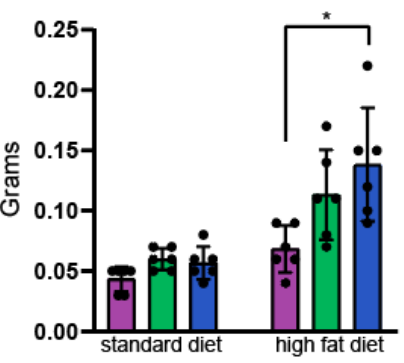

D

Standard diet other depot weights

E

High fat diet other depot weights
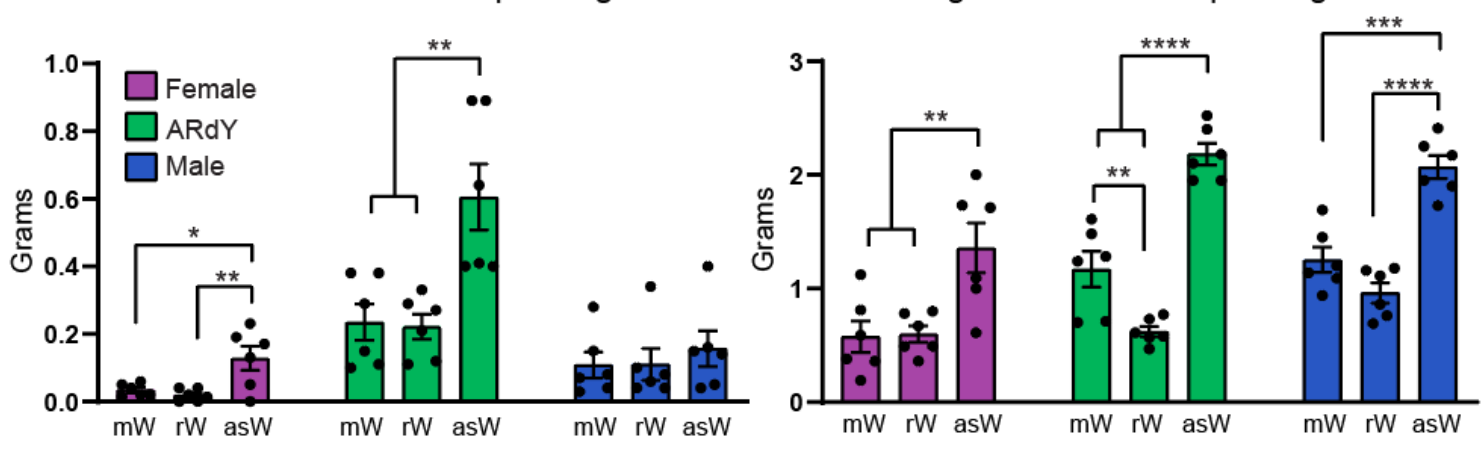

F

Perigonadal WAT G

G Inguinal WAT

$\mathrm{H}$

E18.5 to P18 adipogenesis
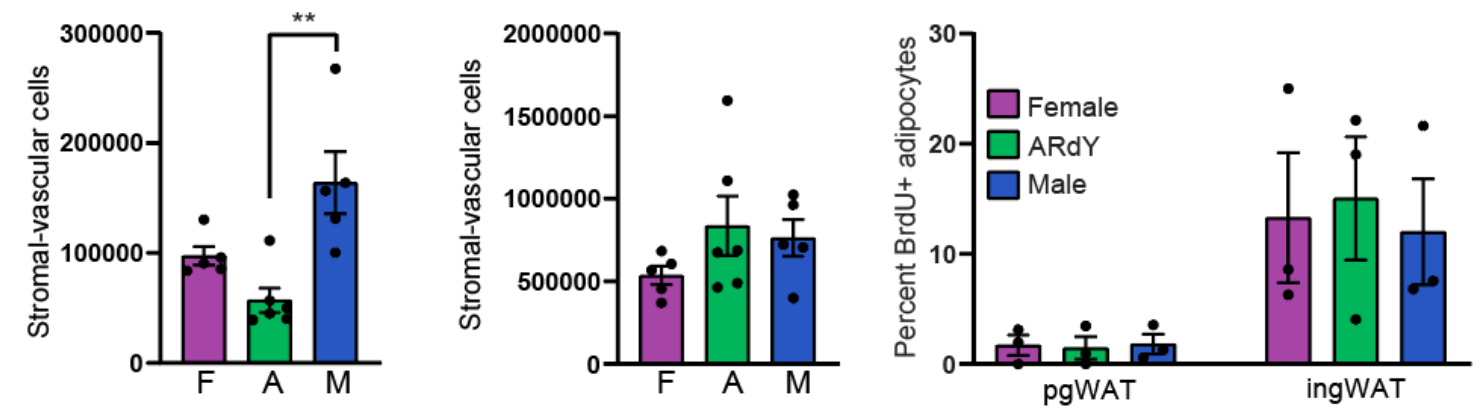

Supplementary Figure 4. Additional depot weights and adipogenesis in female, male and ARdY mice.

(A) pgWAT and ingWAT weights on standard diet $(n=6)$

(B) pgWAT and ingWAT weights on high fat diet $(n=6)$.

(C) mWAT, rWAT, asWAT and BAT depot weights on standard diet $(n=6)$.

(D) mWAT, rWAT, asWAT and BAT depot weights on high fat diet $(n=6)$.

(E) total stromal vascular cells in pgWAT in 18-21 day old mice $(n=5-6)$.

(F) total stromal vascular cells in ingWAT in 18-21 day old mice $(n=5-6)$.

(G) New adipocyte formation from E18.5 to P18 in pgWAT and ingWAT $(n=3)$.

Note: Statistical significance was determined using unpaired Student's t-tests in $(A)$ and $(B)$ and one-way ANOVA with Tukey's multiple comparison's test in (C-G). pg = perigonadal, ing = inguinal, $\mathrm{mW}=$ mesenteric, $r \mathrm{~W}=$ retroperitoneal, asW = anterior subcutaneous, BAT = brown adipose tissue. 


\section{References}

ABREU-VIEIRA, G., FISCHER, A. W., MATTSSON, C., DE JONG, J. M., SHABALINA, I. G., RYDÉN, M., LAURENCIKIENE, J., ARNER, P., CANNON, B. \& NEDERGAARD, J. 2015. Cidea improves the metabolic profile through expansion of adipose tissue. Nature Communications, 6, 1-16.

AGUILAR-SALINAS, C. A., GARCÍA, E. G., ROBLES, L., RIANO, D., RUIZ-GOMEZ, D. G., GARCÍA-ULLOA, A. C., MELGAREJO, M. A., ZAMORA, M., GUILLEN-PINEDA, L. E. \& MEHTA, R. 2008. High adiponectin concentrations are associated with the metabolically healthy obese phenotype. The Journal of Clinical Endocrinology \& Metabolism, 93, 4075-4079.

AHL, S., GUENTHER, M., ZHAO, S., JAMES, R., MARKS, J., SZABO, A. \& KIDAMBI, S. 2015. Adiponectin levels differentiate metabolically healthy vs unhealthy among obese and nonobese white individuals. The Journal of Clinical Endocrinology \& Metabolism, 100, 4172-4180.

BERRY, R. \& RODEHEFFER, M. S. 2013. Characterization of the adipocyte cellular lineage in vivo. Nature cell biology, 15, 302-308.

BJÖRNTORP, P. 1990. " Portal" adipose tissue as a generator of risk factors for cardiovascular disease and diabetes. Arteriosclerosis: An Official Journal of the American Heart Association, Inc., 10, 493-496.

BOEHMER, A. L., BRÜGGENWIRTH, H., VAN ASSENDELFT, C., OTTEN, B. J., VERLEUN-MOOIJMAN, M. C., NIERMEIJER, M. F., BRUNNER, H. G., ROUWÉ, C. W., WAELKENS, J. \& OOSTDIJK, W. 2001. Genotype versus phenotype in families with androgen insensitivity syndrome. The Journal of Clinical Endocrinology \& Metabolism, 86, 4151-4160.

BUEMANN, B., ASTRUP, A., PEDERSEN, O., BLACK, E., HOLST, C., TOUBRO, S., ECHWALD, S., HOLST, J. J., RASMUSSEN, C. \& SØRENSEN, T. I. 2006. Possible role of adiponectin and insulin sensitivity in mediating the favorable effects of lower body fat mass on blood lipids. The Journal of Clinical Endocrinology \& Metabolism, 91, 1698-1704.

BUEMANN, B., SØRENSEN, T., PEDERSEN, O., BLACK, E., HOLST, C., TOUBRO, S., ECHWALD, S., HOLST, J. J., RASMUSSEN, C. \& ASTRUP, A. 2005. Lower-body fat mass as an independent marker of insulin sensitivity-the role of adiponectin. International journal of obesity, 29, 624-631.

CAREY, D. G., COWIN, G. J., GALLOWAY, G. J., JONES, N. P., RICHARDS, J. C., BISWAS, N. \& DODDRELL, D. M. 2002. Effect of Rosiglitazone on Insulin Sensitivity and Body Composition in Type 2 Diabetic Patients: The online title of this article has been corrected and is different from the printed version. Obesity research, 10, 1008-1015.

CARPENTER, A. E., JONES, T. R., LAMPRECHT, M. R., CLARKE, C., KANG, I. H., FRIMAN, O., GUERTIN, D. A., CHANG, J. H., LINDQUIST, R. A. \& MOFFAT, J. 2006. CellProfiler: image analysis software for identifying and quantifying cell phenotypes. Genome biology, 7, R100.

CARR, M. C. \& BRUNZELL, J. D. 2004. Abdominal obesity and dyslipidemia in the metabolic syndrome: importance of type 2 diabetes and familial combined hyperlipidemia in coronary artery disease risk. The journal of clinical endocrinology \& metabolism, 89, 2601-2607.

CHIA, C. W., EGAN, J. M. \& FERRUCCI, L. 2018. Age-related changes in glucose metabolism, hyperglycemia, and cardiovascular risk. Circulation research, 123, 886-904.

CHUSYD, D. E., WANG, D., HUFFMAN, D. M. \& NAGY, T. R. 2016. Relationships between rodent white adipose fat pads and human white adipose fat depots. Frontiers in nutrition, 3, 10.

CNOP, M., HAVEL, P. J., UTZSCHNEIDER, K., CARR, D., SINHA, M., BOYKO, E., RETZLAFF, B., KNOPP, R., BRUNZELL, J. \& KAHN, S. E. 2003. Relationship of adiponectin to body fat distribution, insulin sensitivity and plasma lipoproteins: evidence for independent roles of age and sex. Diabetologia, 46, 459-469. 
DUBOIS, V., LAURENT, M. R., JARDI, F., ANTONIO, L., LEMAIRE, K., GOYVAERTS, L., DELDICQUE, L., CARMELIET, G., DECALLONNE, B. \& VANDERSCHUEREN, D. 2016. Androgen deficiency exacerbates high-fat diet-induced metabolic alterations in male mice. Endocrinology, 157, 648-665.

FAN, W., YANASE, T., NOMURA, M., OKABE, T., GOTO, K., SATO, T., KAWANO, H., KATO, S. \& NAWATA, H. 2005. Androgen receptor null male mice develop late-onset obesity caused by decreased energy expenditure and lipolytic activity but show normal insulin sensitivity with high adiponectin secretion. Diabetes, 54, 1000-1008.

FOSTER, M. T., SOFTIC, S., CALDWELL, J., KOHLI, R., ANNETTE, D. \& SEELEY, R. J. 2013. Subcutaneous adipose tissue transplantation in diet-induced obese mice attenuates metabolic dysregulation while removal exacerbates it. Physiological reports, 1.

GAVRILOVA, O., MARCUS-SAMUELS, B., GRAHAM, D., KIM, J. K., SHULMAN, G. I., CASTLE, A. L., VINSON, C., ECKHAUS, M. \& REITMAN, M. L. 2000. Surgical implantation of adipose tissue reverses diabetes in lipoatrophic mice. The Journal of clinical investigation, 105, 271-278.

GEER, E. B. \& SHEN, W. 2009. Gender differences in insulin resistance, body composition, and energy balance. Gender medicine, 6, 60-75.

GOSS, A. M., GOREE, L. L., ELLIS, A. C., CHANDLER-LANEY, P. C., CASAZZA, K., LOCKHART, M. E. \& GOWER, B. A. 2013. Effects of diet macronutrient composition on body composition and fat distribution during weight maintenance and weight loss. Obesity, 21, 1139-1142.

GOTTLIEB, B. \& TRIFIRO, M. A. 2017. Androgen insensitivity syndrome. GeneReviews ${ }^{\circledR}[$ Internet]. University of Washington, Seattle.

HAMDY, O., PORRAMATIKUL, S. \& AL-OZAIRI, E. 2006. Metabolic obesity: the paradox between visceral and subcutaneous fat. Current diabetes reviews, 2, 367-373.

HAN, J., LEE, J.-E., JIN, J., LIM, J. S., OH, N., KIM, K., CHANG, S.-I., SHIBUYA, M., KIM, H. \& KOH, G. Y. 2011. The spatiotemporal development of adipose tissue. Development, 138, 5027-5037.

HARDY, O. T., CZECH, M. P. \& CORVERA, S. 2012. What causes the insulin resistance underlying obesity? Current opinion in endocrinology, diabetes, and obesity, 19, 81.

HARTZ, A. J., RUPLEY JR, D. C., KALKHOFF, R. D. \& RIMM, A. A. 1983. Relationship of obesity to diabetes: influence of obesity level and body fat distribution. Preventive medicine, 12, 351-357.

HE, W., BARAK, Y., HEVENER, A., OLSON, P., LIAO, D., LE, J., NELSON, M., ONG, E., OLEFSKY, J. M. \& EVANS, R. M. 2003. Adipose-specific peroxisome proliferator-activated receptor $\gamma$ knockout causes insulin resistance in fat and liver but not in muscle. Proceedings of the National Academy of Sciences, 100, 15712-15717.

HEID, I. M., JACKSON, A. U., RANDALL, J. C., WINKLER, T. W., QI, L., STEINTHORSDOTTIR, V., THORLEIFSSON, G., ZILLIKENS, M. C., SPELIOTES, E. K. \& MÄGI, R. 2010. Meta-analysis identifies 13 new loci associated with waist-hip ratio and reveals sexual dimorphism in the genetic basis of fat distribution. Nature genetics, 42, 949-960.

HOLTRUP, B., CHURCH, C. D., BERRY, R., COLMAN, L., JEFFERY, E., BOBER, J. \& RODEHEFFER, M. S. 2017. Puberty is an important developmental period for the establishment of adipose tissue mass and metabolic homeostasis. Adipocyte, 6, 224-233.

JEFFERY, E., CHURCH, C. D., HOLTRUP, B., COLMAN, L. \& RODEHEFFER, M. S. 2015. Rapid depot-specific activation of adipocyte precursor cells at the onset of obesity. Nature cell biology, 17, 376-385.

JO, J., GAVRILOVA, O., PACK, S., JOU, W., MULLEN, S., SUMNER, A. E., CUSHMAN, S. W. \& PERIWAL, V. 2009. Hypertrophy and/or hyperplasia: dynamics of adipose tissue growth. PLoS computational biology, 5.

JOSEPH, G. Y., JAVORSCHI, S., HEVENER, A. L., KRUSZYNSKA, Y. T., NORMAN, R. A., SINHA, M. \& OLEFSKY, J. M. 2002. The effect of thiazolidinediones on plasma adiponectin levels in normal, obese, and type 2 diabetic subjects. Diabetes, 51, 2968-2974. 
KARPE, F. \& PINNICK, K. E. 2015. Biology of upper-body and lower-body adipose tissue-link to wholebody phenotypes. Nature Reviews Endocrinology, 11, 90-100.

KIM, J.-Y., VAN DE WALL, E., LAPLANTE, M., AZZARA, A., TRUJILLO, M. E., HOFMANN, S. M., SCHRAW, T., DURAND, J. L., LI, H. \& LI, G. 2007. Obesity-associated improvements in metabolic profile through expansion of adipose tissue. The Journal of clinical investigation, 117, 2621-2637.

KUBOTA, N., TERAUCHI, Y., KUBOTA, T., KUMAGAI, H., ITOH, S., SATOH, H., YANO, W., OGATA, H., TOKUYAMA, K. \& TAKAMOTO, I. 2006. Pioglitazone ameliorates insulin resistance and diabetes by both adiponectin-dependent and-independent pathways. Journal of Biological Chemistry, 281, 8748-8755.

LOGAN, M., MARTIN, J. F., NAGY, A., LOBE, C., OLSON, E. N. \& TABIN, C. J. 2002. Expression of Cre Recombinase in the developing mouse limb bud driven by a Prxl enhancer. genesis, 33, 77-80.

LYON, M. F. \& HAWKES, S. G. 1970. X-linked gene for testicular feminization in the mouse. Nature, 227, 1217-1219.

MANOLOPOULOS, K., KARPE, F. \& FRAYN, K. 2010. Gluteofemoral body fat as a determinant of metabolic health. International journal of obesity, 34, 949-959.

MIYAZAKI, Y., MAHANKALI, A., MATSUDA, M., MAHANKALI, S., HARDIES, J., CUSI, K., MANDARINO, L. J. \& DEFRONZO, R. A. 2002. Effect of pioglitazone on abdominal fat distribution and insulin sensitivity in type 2 diabetic patients. The Journal of Clinical Endocrinology \& Metabolism, 87, 2784-2791.

MONGAN, N. P., TADOKORO-CUCCARO, R., BUNCH, T. \& HUGHES, I. A. 2015. Androgen insensitivity syndrome. Best practice \& research Clinical endocrinology \& metabolism, 29, 569-580.

MORI, Y., MURAKAWA, Y., OKADA, K., HORIKOSHI, H., YOKOYAMA, J., TAJIMA, N. \& IKEDA, Y. 1999. Effect of troglitazone on body fat distribution in type 2 diabetic patients. Diabetes care, 22, 908-912.

NORRIS, A. W., CHEN, L., FISHER, S. J., SZANTO, I., RISTOW, M., JOZSI, A. C., HIRSHMAN, M. F., ROSEN, E. D., GOODYEAR, L. J. \& GONZALEZ, F. J. 2003. Muscle-specific PPARY-deficient mice develop increased adiposity and insulin resistance but respond to thiazolidinediones. The Journal of clinical investigation, 112, 608-618.

PALMER, B. F. \& CLEGG, D. J. 2015. The sexual dimorphism of obesity. Molecular and cellular endocrinology, 402, 113-119.

PANIAGUA, J. A., DE LA SACRISTANA, A. G., ROMERO, I., VIDAL-PUIG, A., LATRE, J., SANCHEZ, E., PEREZMARTINEZ, P., LOPEZ-MIRANDA, J. \& PEREZ-JIMENEZ, F. 2007. Monounsaturated fat-rich diet prevents central body fat distribution and decreases postprandial adiponectin expression induced by a carbohydrate-rich diet in insulin-resistant subjects. Diabetes care, 30, 1717-1723.

RODEHEFFER, M. S., BIRSOY, K. \& FRIEDMAN, J. M. 2008. Identification of white adipocyte progenitor cells in vivo. Cell, 135, 240-249.

SANCHEZ-GURMACHES, J. \& GUERTIN, D. A. 2014. Adipocytes arise from multiple lineages that are heterogeneously and dynamically distributed. Nature communications, 5, 1-13.

SANCHEZ-GURMACHES, J., HSIAO, W.-Y. \& GUERTIN, D. A. 2015. Highly selective in vivo labeling of subcutaneous white adipocyte precursors with Prx1-Cre. Stem cell reports, 4, 541-550.

SANCHEZ-GURMACHES, J., HUNG, C.-M., SPARKS, C. A., TANG, Y., LI, H. \& GUERTIN, D. A. 2012. PTEN loss in the Myf5 lineage redistributes body fat and reveals subsets of white adipocytes that arise from Myf5 precursors. Cell metabolism, 16, 348-362.

SATO, T., MATSUMOTO, T., YAMADA, T., WATANABE, T., KAWANO, H. \& KATO, S. 2003. Late onset of obesity in male androgen receptor-deficient (AR KO) mice. Biochemical and biophysical research communications, 300, 167-171.

SEBO, Z. L., JEFFERY, E., HOLTRUP, B. \& RODEHEFFER, M. S. 2018. A mesodermal fate map for adipose tissue. Development, 145. 
SHI, H., STRADER, A. D., WOODS, S. C. \& SEELEY, R. J. 2007. The effect of fat removal on glucose tolerance is depot specific in male and female mice. American Journal of Physiology-Endocrinology and Metabolism, 293, E1012-E1020.

SHULMAN, G. I. 2014. Ectopic fat in insulin resistance, dyslipidemia, and cardiometabolic disease. New England Journal of Medicine, 371, 1131-1141.

SHUNGIN, D., WINKLER, T. W., CROTEAU-CHONKA, D. C., FERREIRA, T., LOCKE, A. E., MÄGI, R., STRAWBRIDGE, R. J., PERS, T. H., FISCHER, K. \& JUSTICE, A. E. 2015. New genetic loci link adipose and insulin biology to body fat distribution. Nature, 518, 187-196.

TANAKA, S., KANEKO, T., MORIYAMA, T. \& MATSUZAWA, A. 1994. A new testicular feminization mutation found in C57BL/6J mice. Laboratory animals, 28, 262-264.

TCHERNOF, A. \& DESPRÉS, J.-P. 2013. Pathophysiology of human visceral obesity: an update. Physiological reviews, 93, 359-404.

TCHKONIA, T., THOMOU, T., ZHU, Y., KARAGIANNIDES, I., POTHOULAKIS, C., JENSEN, M. D. \& KIRKLAND, J. L. 2013. Mechanisms and metabolic implications of regional differences among fat depots. Cell metabolism, 17, 644-656.

YAMASHITA, S., NAKAMURA, T., SHIMOMURA, L., NISHIDA, M., YOSHIDA, S., KOTANI, K., KAMEDATAKEMUARA, K., TOKUNAGA, K. \& MATSUZAWA, Y. 1996. Insulin resistance and body fat distribution: contribution of visceral fat accumulation to the development of insulin resistance and atherosclerosis. Diabetes care, 19, 287-291.

YEH, S., TSAI, M.-Y., XU, Q., MU, X.-M., LARDY, H., HUANG, K.-E., LIN, H., YEH, S.-D., ALTUWAIJRI, S. \& ZHOU, X. 2002. Generation and characterization of androgen receptor knockout (ARKO) mice: an in vivo model for the study of androgen functions in selective tissues. Proceedings of the National Academy of Sciences, 99, 13498-13503.

YKI-JÄRVINEN, H. 2004. Thiazolidinediones. New England Journal of Medicine, 351, 1106-1118. 